\title{
Phytoplankton inhibition of copepod egg hatching: test of an exudate hypothesis
}

\author{
Kam W. Tang* ${ }^{*}$ Hans G. Dam** \\ Department of Marine Sciences, University of Connecticut, Groton, Connecticut 06340, USA
}

\begin{abstract}
Recent papers have reported that certain marine diatoms are deleterious to copepod egg production and hatching. Diatom harmful effects can result from 2 different mechanisms: dietinduced maternal effects and external effects. We conducted 5 separate egg incubation experiments to test if phytoplankton exudates (an external effect) were harmful to copepod eggs. Exudates produced by 3 reportedly toxic diatoms, plus 2 non-diatom species, had no effects on egg hatching in the copepod Acartia tonsa. Thus, phytoplankton exudates are not likely to inhibit egg hatching. A seasonal relationship was observed between egg production and egg hatching of $A$. tonsa such that high egg production rate resulted in high egg hatching success (80 to $100 \%)$, but low egg production rate resulted in highly variable egg hatching success (0 to $90 \%$ ).
\end{abstract}

KEY WORDS: Phytoplankton · Toxicity $\cdot$ Extract $\cdot$ Algal exudate $\cdot$ Egg hatching $\cdot$ Copepod $\cdot$ Acartia tonsa

\section{INTRODUCTION}

Seasonal diatom blooms have long been considered as a major food source for planktonic copepods, and diatoms have been repeatedly used in culturing copepods in the laboratory. However, in recent years, the notion that diatoms have negative effects on marine copepods has provoked re-evaluation of our understanding of diatom-copepod interactions in the ocean (Ban et al. 1997). One example of the negative effect of diatoms is the inhibition of egg hatching (Poulet et al. 1994, Ianora et al. 1995). In the context of food-related effects, more than 1 hypothesis can account for failure of eggs to hatch. One possibility is diet-induced maternal effects: nutritional deficiency of the diets induces the female to produce low-quality eggs (Jónasdóttir \& Kiørboe 1996), or harmful compounds are passed from the mother to the eggs, whose normal development is

\footnotetext{
*Present address: Danish Institute for Fisheries Research, Kavelergarden 6, Charlottenlund 2920, Denmark

**Corresponding author. E-mail: hgdam@uconn.edu
}

then suppressed (suggested by Miralto et al. 1999). Another possibility is external effects, such that the phytoplankton cells release extracellular substances which inhibit normal egg hatching. Many phytoplankton species, including diatoms, are known to naturally release extracellular organic matters, or exudates (Fogg 1983). In addition to a large variety of compounds necessary for cell functioning, some of these exudates contain toxins (Hellebust 1974, Fogg 1983). Phytoplankton exudates can at times constitute an important source of labile organic carbon in the water column (Larsson \& Hagström 1982, Lignell 1990, Baines \& Pace 1991, Malinsky-Rushansky \& Legrand 1996). Phytoplankton exudates may act as a defense mechanism against grazers (Malej \& Harris 1993) and could be encountered by copepod eggs in nature. Therefore, one way in which diatoms may inhibit copepod egg hatching is by releasing harmful exudates into the water column. In the present study we investigate whether exudates naturally released by phytoplankton, including diatoms, affect egg hatching in the copepod Acartia tonsa. 


\section{MATERIALS AND METHODS}

Five phytoplankton species were used in the experiments: Thalassiosira weissflogii, T. rotula, Phaeodactylum tricornutum (diatoms), Isochrysis galbana (prymnesiophyte) and Chroomonas salina (cryptophyte). Cell extracts (different from exudates) of the 3 diatom species have been reported to be harmful to copepod eggs (summarized in Ban et al. 1997). Phytoplankton batch cultures were grown in $\mathrm{f} / 2$ medium (with $\mathrm{Si}$ for diatoms) in 11 polycarbonate bottles at a temperature of $18 \pm 0.5^{\circ} \mathrm{C}$ and a $14: 10 \mathrm{~h}$ light:dark cycle. Growth of the phytoplankton cultures was monitored with an Elzone particle counter at least every other day. Specific growth rate $(r)$ was calculated as: $r=\left(\ln C_{\mathrm{t}}-\right.$ $\left.\ln C_{0}\right) / t$, where $t=$ time in days and $C=$ cell density in $\mathrm{ml}^{-1}$. Phytoplankton exudates were collected when the cultures reached stationary or senescent phase, which is typically the time when exudate concentration is expected to be highest (Bjørnsen 1988). Exudates were collected by filtering the cultures through GF/F filters at a suction pressure of $\leq 75 \mathrm{~mm} \mathrm{Hg}$, followed by either $0.2 \mu \mathrm{m}$ polyacetate membranes or $0.2 \mu \mathrm{m}$ Vacucap (Gelman) at a suction pressure of $\leq 130 \mathrm{~mm} \mathrm{Hg}$. Aliquots of the filtrates were collected for organic carbon measurements; the rest of the filtrates (exudates) were saved in sterile polycarbonate bottles and kept at $-70^{\circ} \mathrm{C}$ until use. Freezing was the same storage procedure employed in some extract studies (e.g. Poulet et al. 1994, Uye 1996). However, unlike the case with extracts, the exudates were prepared by a non-destructive method, and therefore contained only organic
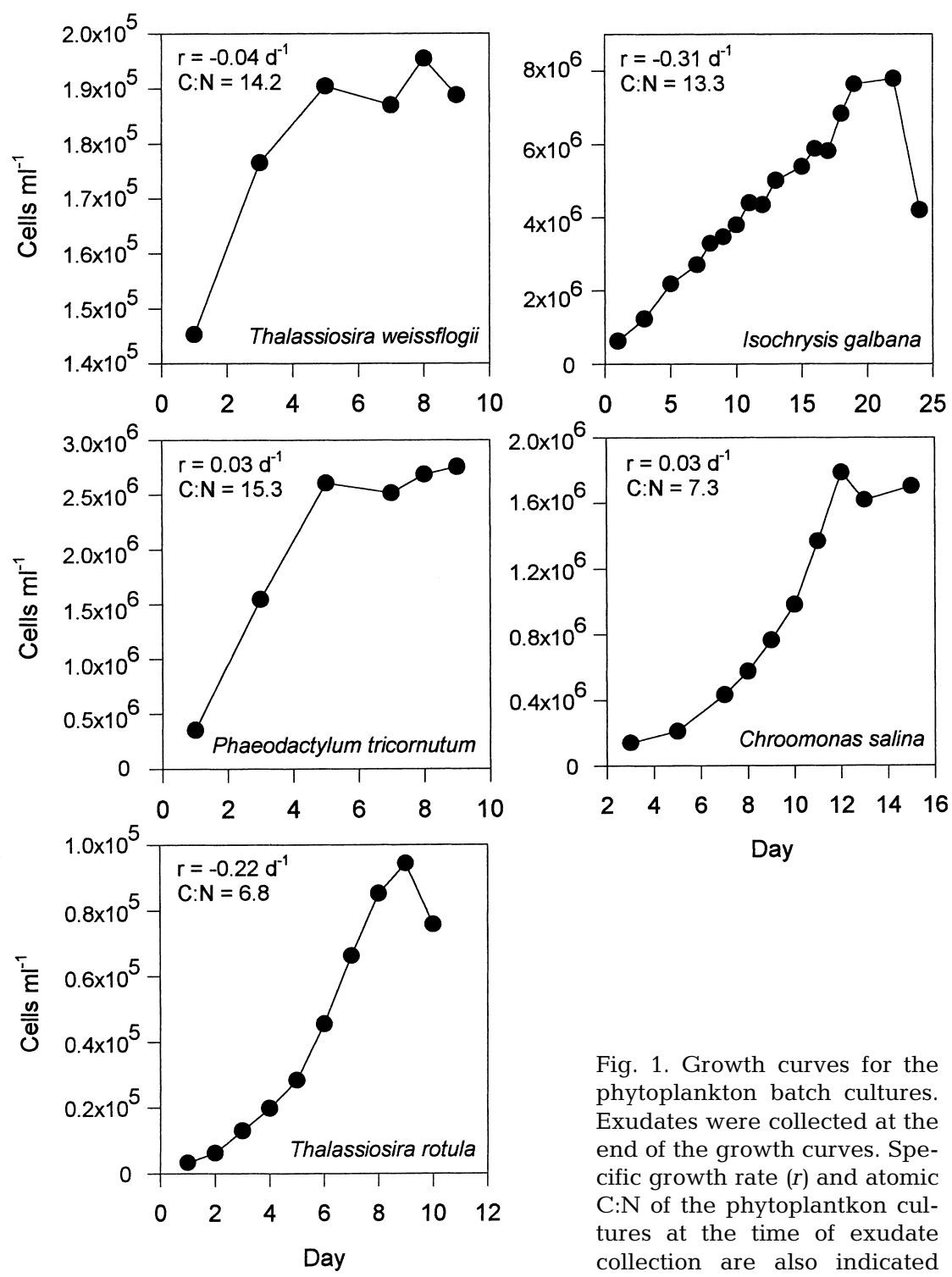

Fig. 1. Growth curves for the phytoplankton batch cultures. Exudates were collected at the end of the growth curves. Specific growth rate $(r)$ and atomic $\mathrm{C}: \mathrm{N}$ of the phytoplantkon cultures at the time of exudate collection are also indicated 
matter that was naturally released from the cells. As a proxy of exudate concentration, the total organic carbon (DOC) of the phytoplankton culture filtrate was measured with the persulfate oxidation method (Williams 1967).

The copepod Acartia tonsa and surface seawater were collected from Long Island Sound, USA, between October and December. Female (with attached spermatophores) and male (with fully developed sex legs) copepods with intact appendages and no visible defects were sorted for the experiments. One male and 10 female copepods were incubated in 11 of $63 \mu \mathrm{m}$ filtered surface seawater ( 3 to 4 bottles) on a spinning plankton wheel. Incubation was done at field temperatures, or when the field temperatures dropped below $10^{\circ} \mathrm{C}$; the copepods were first acclimated to $17^{\circ} \mathrm{C}$ for $1 \mathrm{~d}$ before incubation at $17^{\circ} \mathrm{C}$. After $24 \mathrm{~h}$ of incubation, eggs and nauplii from each bottle were gently collected on a $63 \mu \mathrm{m}$ sieve and counted. When egg production rates were high in the fall, eggs from each bottle were used as a replicate. When egg production rates were low in the winter, eggs from all bottles were pooled and then randomly divided into equal portions for the subsequent experiments.

Exudates collected earlier were thawed to experimental temperatures before use. Batches of about 30 eggs ( 2 to 4 replicates) were briefly rinsed with the exudates, then incubated individually in Corning 96well plates with each well $(6.4 \mathrm{~mm}$ diam. $\times 11 \mathrm{~mm})$ filled up to $80 \%$ with the exudates. Filtered surface seawater was prepared in the same manner as the exudates, and eggs incubated in the filtered seawater were used as control ( 2 to 4 replicates of 30 eggs). Eggs were incubated in the same environmental conditions as the adult copepods, and were examined every day for up to $3 \mathrm{~d}$. About $80 \%$ of the media in the wells was changed daily to minimize hypoxic conditions. We classified our observations into 5 categories: unhatched eggs, normal nauplii, abnormal nauplii, empty egg shells, and missing eggs (Tang et al. 1998). Hatching success was expressed as the percentage of eggs that hatched to normal nauplii at the end of the observation period.

\section{RESULTS AND DISCUSSION}

The phytoplankton populations were decreasing or reaching a plateau at the time of exudate collection, with a specific growth rate that ranged from -0.31 to $0.03 \mathrm{~d}^{-1}$ (Fig. 1). The culture of Isochrysis galbana contained the largest amount of exudate $(12.0 \mathrm{mg}$ DOC $\mathrm{l}^{-1}$ ), followed by Chroomonas salina $(5.2 \mathrm{mg}$ DOC $\mathrm{l}^{-1}$ ). The organic carbon concentration of exudates from the 3 diatom species ranged from 2.60 to

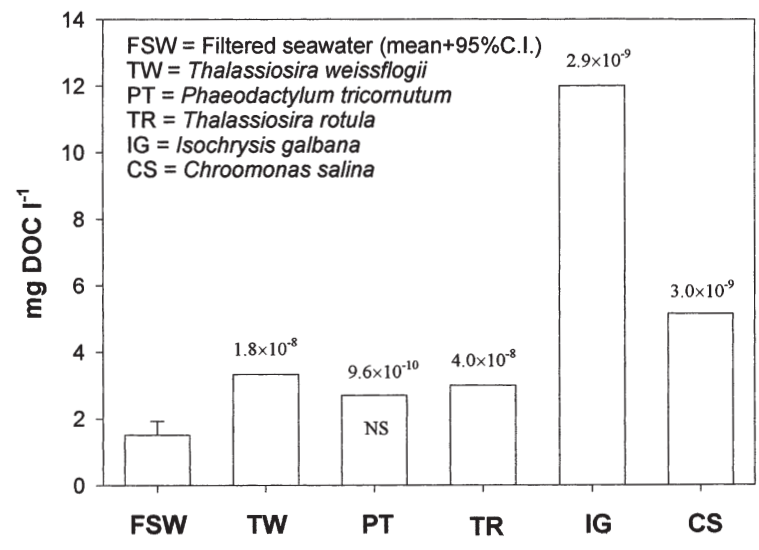

Fig. 2. Total organic carbon content of the exudates and filtered seawater. Filtered seawater was prepared in the same manner as the exudates and was used as the control treatments $(n=9)$. NS: not significantly different from filtered seawater ( $p>0.05)$. Number on top of each bar represents amount of exudate per cell at the time of exudate collection (mg DOC cell $\left.{ }^{-1}\right)$

$3.33 \mathrm{mg} \mathrm{l}^{-1}$ (Fig. 2). When DOC concentration was expressed on a per cell basis, it became clear that the large amount of exudates in I. galbana was a result of high cell abundance, and that Thalassiosira rotula exuded the largest amount of organic matter per cell (Fig. 2). Except for Phaeodactylum tricornutum, all the exudates contained significantly more organic carbon than the filtered seawater (comparison of a single observation with a sample mean, $\mathrm{p}<0.05$, Sokal \& Rohlf 1981).

The egg production rate of Acartia tonsa decreased from about 30 eggs female $\mathrm{e}^{-1} \mathrm{~d}^{-1}$ in October to about 5 eggs female ${ }^{-1} \mathrm{~d}^{-1}$ in December, parallel to a decrease in surface seawater temperature (Fig. 3). A similar seasonal trend was also observed in egg hatching among the control treatments, when the hatching success decreased from nearly $100 \%$ in early October to only about $20 \%$ in December (Fig. 4).

Different exudates were tested at different times between October and December. Effects of the exudates were examined by comparing the hatching success in the exudate treatments with that in the control treatments (Fig. 4). Throughout the entire study, eggs incubated in any of the exudates did not show significantly lower hatching success than those incubated in filtered seawater (Mann-Whitney $U$-test, $\mathrm{p}>0.05$ ). In fact, in 1 case, the exudate treatment resulted in a significantly higher hatching success (indicated by an asterisk in Fig. 4). We found only 9 abnormal nauplii and 5 empty egg shells out of a total of 1925 observations among all the exudate treatments for the entire study.

In the present study, we observed a decrease in egg production rate from September to December. A simi- 


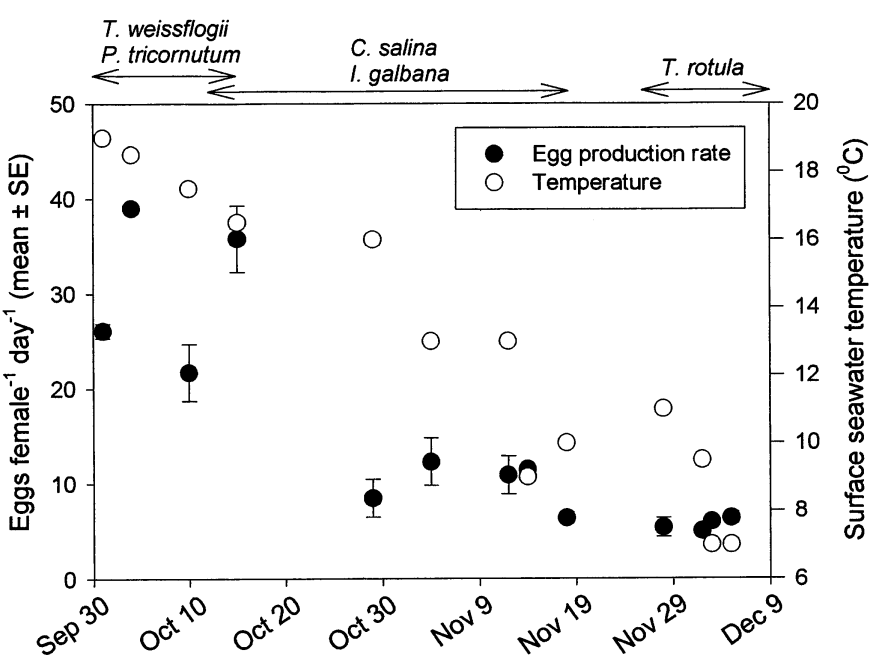

Fig. 3. Egg production rate of the copepod Acartia tonsa and surface seawater temperature during the present study. Arrows at the top indicate when exudates of the phytoplankton species were used for the experiments. Full specific names of phytoplankton as in Figs. 1 \& 2

lar seasonal decrease in egg production rate in Acartia tonsa has been previously reported (Bellantoni \& Peterson 1987, Dam et al. 1994). Such a decrease in reproductive effort of the copepods was parallel to a decrease in water temperature (Fig. 3), and probably a decrease in seston concentration (Dam et al. 1994).

Egg hatching success was not affected by the presence of phytoplankton exudates (Fig. 4). Our experimental design was such that the effects of factors such as female age and condition and fertility did not confound the comparisons between the treatments (exudates) and the control (natural seawater). Whether such factors affected egg hatching in general is not relevant to the hypothesis tested in this study. However, we did observe an interesting seasonal pattern. When hatching success among all treatments (including the control) is plotted against egg production rate (Fig. 5), it becomes clear that in the earlier season, when egg production rate was high ( $\geq 20$ eggs female ${ }^{-1} \mathrm{~d}^{-1}$ ), egg hatching success was also high ( 80 to $100 \%)$. When egg production was low, later in the season $(<20$ eggs female ${ }^{-1} \mathrm{~d}^{-1}$ ), egg hatching success was highly variable (0 to $90 \%$ ). A similar relationship between copepod egg production rate and egg hatching success has been observed before (Guisande \& Harris 1995, Jónasdóttir \& Kiørboe 1996). The pattern cannot be attributed to the effect of the exudates because it was similar for the control and the treatments. Instead, Jónasdóttir \& Kiørboe (1996) have suggested that high egg hatching success is achieved when eggs receive a favorable balance of required nutrients, and that low egg production and hatching rates ensue when some essential nutrients are missing, such as certain essential amino acids (Guisande et al. 1999, but also see Laabir et al. 1999). Further work is needed to test this hypothesis. Another possibility is that the low hatching success observed later in the season is due to the production of resting eggs (Marcus 1990, 1991, 1995).

Reports of the harmful effects of diatoms on copepod egg hatching have stimulated much discussion in recent years. Several questions immediately come to mind: (1) Do diatoms contain any harmful substances? An example of such harmful substances is cytotoxic aldehydes of low molecular weight that have been isolated from the diatom Thalassiosira rotula as secondary metabolites (Ianora et al. 1999). Production of low molecular weight aldehydes by phytoplankton has been reported before (Collins \& Bean 1963, Nuccio et al. 1995). The same group of compounds has been found to block cell cleavage in sea urchins (Buttino et al. 1999, citations in Ianora et al. 1999) and in copepods (Miralto et al. 1999). Therefore, there is a possibility that diatoms could be harmful to copepod eggs due to the action of these aldehydes. Yet one needs to consider: (2) Do these harmful substances exert their

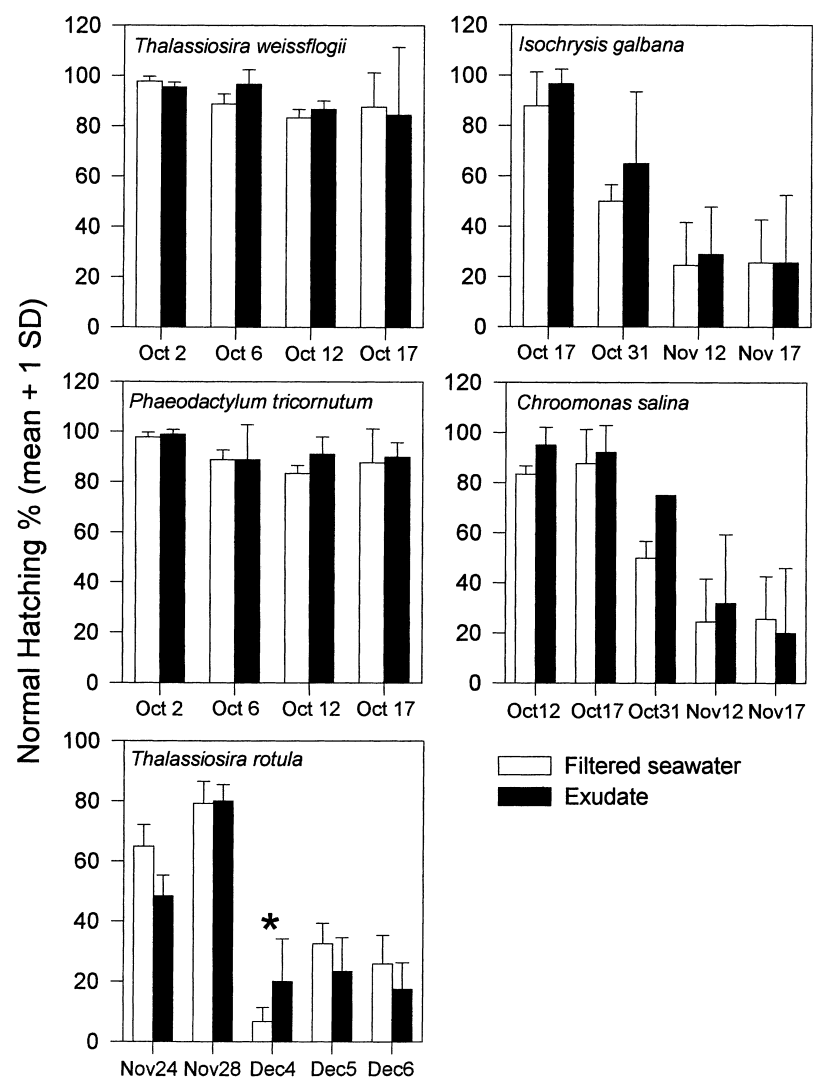

Fig. 4. Acartia tonsa. Hatching success of eggs (= \% hatched to normal nauplii). No significant difference between exudate treatments (black bars) and filtered seawater treatments (white bars) (Mann-Whitney $U$-test, $\mathrm{p}>0.05$ ) except in 1 case (indicated by $*, \mathrm{p}<0.05$ ) 


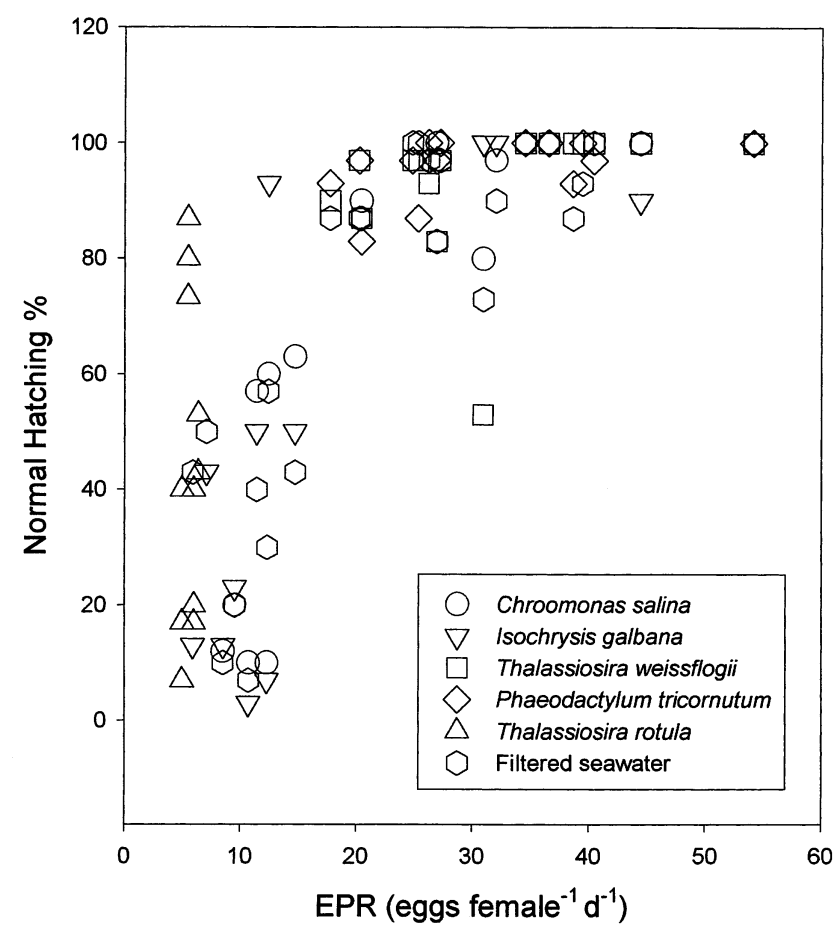

Fig. 5. Acartia tonsa. Relationship betwen egg production rate (EPR) and egg hatching success

effects through contact with copepod eggs in the water column (external effects), or within the female body (maternal effects)? In the present study, we tested if diatoms and other phytoplankters produce harmful extracellular products that inhibit copepod egg hatching. In our experiments, the phytoplankton exudates were collected at a cell concentration of $10^{4}$ to $10^{6} \mathrm{ml}^{-1}$ (Fig. 1). Cell extracts of the same diatom cell concentrations have been found to be deleterious to copepod eggs (Poulet et al. 1994, 1995, Ianora et al. 1995, Miralto et al. 1995, Jónasdóttir \& Kiørboe 1996, Uye 1996, Ban et al. 1997), although in Arartia tonsa the deleterious effect of the extract disappears when the extract is aerated (Jónasdóttir \& Kiørboe 1996). However, in the present study, exudates produced by the same concentrations of either the 3 diatom species or the 2 non-diatom species had no negative effects on copepod egg hatching. Thus, our results suggest that even if diatoms are harmful, the harmful effects cannot be a result of encounter between spawned copepod eggs and diatom cell products in the water column. In a study with sea urchin eggs, Poulet et al. (1994) also noticed that the harmful effects of diatom 'extracts' were not reproduced when 'exudates' were used instead. This negative result is perhaps not surprising since the evolutionary significance of phytoplankton extracellular products as allelopathic agents is controversial (Lewis 1986).
Thus, a question that remains is: (3) Do diatoms affect copepod egg hatching by inducing the female copepods to produce low-quality eggs after the diatom cells are ingested (i.e. maternal effects). Evidence for maternal effects has been reported such that copepods fed only diatoms had lower egg production rates and hatching success compared to those fed dinoflagellates (Ianora \& Poulet 1993, Poulet et al. 1994, Ianora et al. 1995, Laabir et al. 1995, Miralto et al. 1995, Chaudron et al. 1996, Ianora et al. 1996, Uye 1996). However, monospecific diet experiments do not tell us the true nature of the maternal effects: are the reduced egg production rate and hatching success results of poor nutritional quality of the diatoms (nutritional effects), or toxic constituents of the diatoms (toxic effects) (Jónasdóttir et al. 1998)? Although toxic compounds have been isolated from certain diatoms (Miralto et al. 1999), it remains to be demonstrated that the female copepods actually absorb these compounds through ingestion, and eventually deposit these compounds in eggs, resulting in low hatching success (Chaudron et al. 1996).

Acknowledgements. We thank M. Trahiotis for performing the TOC analyses. This study was supported by NSF OCE9521907 (CAREER) awarded to H.G.D. The Marine Science and Technology Center of the University of Connecticut (MSTC, UCONN) provided the research vessels. We thank 4 anonymous reviewers, and the Contributing Editor, $\mathrm{M}$. Landry, for their comments and suggestions. This is contribution no. 311 of the MSTC, UCONN.

\section{LITERATURE CITED}

Baines SB, Pace ML (1991) The production of dissolved organic matter by phytoplankton and its importance to bacteria: patterns across marine and freshwater systems. Limnol Oceanogr 36:1078-1090

Ban S and 22 others (1997) The paradox of diatom-copepod interactions. Mar Ecol Prog Ser 157:287-293

Bellantoni DC, Peterson WT (1987) Temporal variability in egg production rates of Acartia tonsa Dana in Long Island Sound. J Exp Mar Biol Ecol 107:199-208

Bjørnsen PK (1988) Phytoplankton exudation of organic matter: why do healthy cells do it? Limnol Oceanogr 33: 151-154

Buttino I, Miralto A, Ianora A, Romano G, Poulet SA (1999) Water-soluble extracts of the diatom Thalassiosira rotula induce aberrations in embryonic tubulin organisation of the sea urchin Paracentrotus lividus. Mar Biol 134: $147-154$

Chaudron Y, Poulet SA, Laabir M, Ianora A, Miralto A (1996) Is hatching success of copepod eggs diatom densitydependent? Mar Ecol Prog Ser 144:185-193

Collins R, Bean G (1963) Volatile constituents obtained from Clamydomonas globosa, the carbonyl fraction. Phycologia 3:55-59

Dam HG, Peterson WT, Bellantoni DC (1994) Seasonal feeding and fecundity of the calanoid copepod Acartia tonsa in Long Island Sound: is omnivory important to egg production? Hydrobiologia 292/293:191-199 
Fogg GE (1983) The ecological significance of extracellular products of phytoplankton photosynthesis. Bot Mar 26: 3-14

Guisande C, Harris R (1995) Effect of total organic content of eggs on hatching success and naupliar survival in the copepod Calanus helgolandicus. Limnol Oceanogr 40:476-482

Guisande C, Maneiro I, Riveiro I (1999) Homeostasis in the essential amino acid composition of the marine copepod Euterpina acutifrons. Limnol Oceanogr 44:691-696

Hellebust JA (1974) Extracellular products. In: Stewart WPD (ed) Algal physiology and biochemistry. Blackwell, Oxford, p 838-863

Ianora A, Poulet SA (1993) Egg viability in the copepod Temora stylifera. Limnol Oceanogr 38:1615-1626

Ianora A, Poulet SA, Miralto A (1995) A comparative study of the inhibitory effect of diatoms on the reproductive biology of the copepod Temora stylifera. Mar Biol 121:533-539

Ianora A, Poulet SA, Miralto A, Grottoli R (1996) The diatom Thalassiosira rotula affects reproductive success in the copepod Acartia clausi. Mar Biol 125:279-286

Ianora A, Miralto A, Poulet SA (1999) Are diatoms good or toxic for copepods? Reply to comment by Jónasdóttir et al. Mar Ecol Prog Ser 177:305-308

Jónasdóttir SH, Kiørboe T (1996) Copepod recruitment and food composition: do diatoms affect hatching success? Mar Biol 125:743-750

Jónasdóttir SH, Kiørboe T, Tang KW, St John M, Visser AW, Saiz E, Dam HG (1998) Role of diatoms in copepod production: good, harmless or toxic? Mar Ecol Prog Ser 172: 305-308

Laabir M, Poulet SA, Ianora A, Miralto A, Cueff A (1995) Reproductive response of Calanus helgolandicus. II. In situ inhibition of embryonic development. Mar Ecol Prog Ser 129:97-105

Laabir M, Poulet SA, Cueff A, Ianora A (1999) Effect of diet on levels of amino acids during embryonic and naupliar development of the copepod Calanus helgolandicus. Mar Biol 134:89-98

Larsson U, Hagström A (1982) Fractionated phytoplankton primary production, exudate release and bacterial production in a Baltic eutrophication gradient. Mar Biol 67: $57-70$

Lignell R (1990) Excretion of organic carbon by phytoplankton: its relation to algal biomass, primary productivity and bacterial secondary productivity in the Baltic Sea. Mar Ecol Prog Ser 68:85-99

Lewis WM Jr (1986) Evolutionary interpretations of allelochemical interactions in phytoplankton algae. Am Nat 127:184-194

Editorial responsibility: Michael Landry (Contributing Editor), Honolulu, Hawaii, USA
Malej A, Harris RP (1993) Inhibition of copepod grazing by diatom exudates: a factor in the development of mucus aggregates? Mar Ecol Prog Ser 96:33-42

Malinsky-Rushansky NZ, Legrand C (1996) Excretion of dissolved organic carbon by phytoplankton of different sizes and subsequent bacterial uptake. Mar Ecol Prog Ser 132: 249-255

Marcus NH (1990) Calanoid copepod, cladoceran, and rotifer eggs in sea-bottom sediments of northern Californian coastal waters: identification, occurrence and hatching. Mar Biol 105:413-418

Marcus NH (1991) Planktonic copepods in a sub-tropical estuary: seasonal patterns in the abundance of adults, copepodites, nauplii, and eggs in the sea bed. Biol Bull (Wash) 181:269-274

Marcus NH (1995) Seasonal study of planktonic copepods and their benthic resting eggs in northern California coastal waters. Mar Biol 123:459-465

Miralto A, Ianora A, Poulet SA (1995) Food type induces different reproductive responses in the copepod Centropages typicus. J Plankton Res 17:1521-1534

Miralto A, Barone G, Romano G, Poulet SA, Ianora A, Russo GL, Buttino I, Mazzarella G, Laabir M, Cabrini M, Giacobbe MG (1999) The insidious effect of diatoms on copepod reproduction. Nature 402:173-176

Nuccio J, Seaton PJ, Kieber RJ (1995) Biological production of formaldehyde in the marine environment. Limnol Oceanogr 40:521-527

Poulet SA, Ianora A, Miralto A, Meijer L (1994) Do diatoms arrest embryonic development in copepods? Mar Ecol Prog Ser 111:79-86

Poulet SA, Laabir M, Ianora A, Miralto A (1995) Reproductive response of Calanus helgolandicus. I. Abnormal embryonic and naupliar development. Mar Ecol Prog Ser 129: $85-95$

Sokal RR, Rohlf FJ (1981) Biometry. The principles and practice of statistics in biological research, 2 nd edn. WH Freeman \& Co, New York

Tang KW, Dam HG, Feinberg LR (1998) The relative importance of egg production rate, hatching success, hatching duration and egg sinking in population recruitment of two species of marine copepods. J Plankton Res 20:1971-1987

Uye S (1996) Induction of reproductive failure in the planktonic copepod Calanus pacificus by diatoms. Mar Ecol Prog Ser 133:89-97

Williams PM (1967) Sea surface chemistry: organic carbon and organic and inorganic nitrogen and phosphorus in surface films and subsurface waters. Deep-Sea Res 14: $791-800$

Submitted: November 25, 1999; Accepted: July 13, 2000

Proofs received from author(s): November 27, 2000 